\title{
Smooth Muscle Antibody Measurement
}

National Cancer Institute

\section{Source}

National Cancer Institute. Smooth Muscle Antibody Measurement. NCI Thesaurus. Code C111317.

The determination of the amount of smooth muscle antibody present in a sample. 